\title{
Proposal of a trophic state index in semiarid reservoirs using data of the Banabuiú Basin, state of Ceará, Brazil
}

Proposta de índice de estado trófico em reservatórios do semiárido a partir de dados da bacia do Banabuiú, estado do Ceará, Brasil

Hosineide de Oliveira Rolim* (D), Ana Bárbara de Araújo Nunes² (D),

Francisco Jonathan de Sousa Cunha Nascimento ${ }^{1}$ (D) and Jarbas Rodrigues Chaves ${ }^{1}$ (D)

${ }^{1}$ Instituto Federal de Educação, Ciência e Tecnologia do Ceará, Campus Limoeiro do Norte, Bloco 2, CEP 62930-000, Limoeiro do Norte, CE, Brasil

${ }^{2}$ Centro de Tecnologia, Departamento de Engenharia Hidráulica e Ambiental, Universidade Federal do Ceará, Campus do Pici, Bloco 713, CEP 60440-970, Fortaleza, CE, Brasil

*hosineide@ifce.edu.br

Cite as: Rolim, H.O. et al. Proposal of a trophic state index in semiarid reservoirs using data of the Banabuiú Basin, state of Ceará, Brazil. Acta Limnologica Brasiliensia, 2019, vol. 31, e26.

Abstract: Aim: This study aimed to develop a Trophic State Index that simulates the cumulative impact in 18 reservoirs in the Banabuiú basin, located in the semiarid region of the State of Ceará. Methods: Analyses were made for physical (temperature, transparency and turbidity), chemical (dissolved oxygen, $\mathrm{pH}$ and total phosphorus) and biological (chlorophyll-a) variables as indicators of reservoir water quality. Data used in this study were made available by the Water Resources Management Company of the State of Ceará (COGERH), in the years between 2010 and 2013. An adaptation was developed for trophic classification $\left(\mathrm{TSI}_{\mathrm{SA}}\right)$, incorporating the three most relevant variables for trophic evaluation, total phosphorus, chlorophyll-a and transparency. For interpreting the data set, we used multivariate statistics as Hierarchical Cluster Analysis (HCA) and Factor Analysis/Principal Component Analysis (PCA). Results: The similarity of Banabuiú basin reservoirs in relation to water eutrophication gave rise to three distinct groups: I, II and III consisting of nine, four and five reservoirs, respectively. The calculation of minimum and maximum values and percentiles of the correlated parameters defined four classes of trophic state; it was observed that the reservoirs in the group I showed trophic classification predominantly between oligotrophic (54.7\%), mesotrophic $(30.2 \%)$, group II, eutrophic (44.4\%) and hypertrophic (33.3\%) and those of the group III, eutrophic $(39.1 \%)$ and hypertrophic $(60.9 \%)$. Conclusion: The TSI $_{\mathrm{SA}}$ presented a simple methodology and easy interpretation of the data, grounded in the quality of water of reservoirs located in the semiarid region of Ceará. Thus, its use can contribute for the reduction of errors in the inference of the trophic state of reservoirs in this region and should be considered as an indicator for more detailed studies.

Keywords: index; eutrophication; water quality; Ceará semiarid region.

Resumo: Objetivo: O presente trabalho teve como objetivo desenvolver um Índice de Estado Trófico que simule o impacto cumulativo em 18 reservatórios da bacia hidrográfica do Banabuiú, localizada no semiárido cearense. Métodos: Foram analisadas variáveis físicas (temperatura, transparência e turbidez), químicas (oxigênio dissolvido, $\mathrm{pH}$ e fósforo total) e biológica (clorofila a) como indicadoras da qualidade da água dos reservatórios. Os dados utilizados neste trabalho foram disponibilizados pela Companhia de Gestão dos Recursos Hídricos do Estado do Ceará (COGERH), 
nos anos compreendidos entre 2010 e 2013. Foi desenvolvido uma adaptação para classificação trófica $\left(\mathrm{IET}_{\mathrm{SA}}\right)$, incorporando as três variáveis mais relevantes para avaliação trófica de reservatórios, Fósforo Total, Clorofila a e Transparência. Para interpretar o conjunto de dados foram utilizadas técnicas de estatística multivariada como Análise de Agrupamento Hierárquico (AAH) e Análise Fatorial/Análise de Componentes Principais (PCA). Resultados: A semelhança dos reservatórios da bacia do Banabuiú, em relação à eutrofização das águas deu origem a três grupos distintos, sendo os grupos I, II e III compostos por, nove, quatro e cinco reservatórios, respectivamente. A partir do cálculo dos valores mínimos e máximos e percentis dos parâmetros correlacionados, estabeleceu-se quatro classes de estado trófico e observou-se que os reservatórios inseridos no grupo I, apresentaram classificaçáo trófica predominantemente entre oligotrófico $(54,7 \%)$, mesotrófico $(30,2 \%)$, os do grupo II, eutrófico $(44,4 \%)$ e hipereutrófico $(33,3 \%)$ e os que compóem o grupo III, eutrófico $(39,1 \%)$ e hipereutrófico $(60,9 \%)$. Conclusóes: $\mathrm{O}_{\text {IET }}$, apresentou uma metodologia simples e de fácil interpretação dos dados, fundamentada na qualidade das águas dos reservatórios localizados no semiárido cearense. Logo a sua utilização pode contribuir para redução dos erros na inferência do estado trófico de reservatórios dessa região e deve ser visto como um indicativo para estudos mais aprofundados.

Palavras-chave: indicador; eutrofização; qualidade de água; semiárido cearense.

\section{Introduction}

Water is an indispensable and irreplaceable natural resource, since it is an essential element for the development of all life forms on the planet. For human society, water is directly associated with the health and comfort of populations (Pegorini et al., 2005).

The problem of water shortage and the inappropriate use of natural resources is worse in semiarid regions, such as Northeast Brazil, where natural resources, particularly soil and water, are limited and constitute fragile ecosystems. These regions are characterized by water deficit and high positive balance of solar energy, which has contributed to high evaporative rates of water bodies. However, the water shortage in the semiarid region is not only related to the rainfall regime of the region, but also to determining factors, such as shallow soils, high evaporative demand, removal of natural vegetation cover and social organization (Andrade et al., 2010).

To meet the water shortage imposed by these environmental constraints, the Northeastern region has a large network of artificial reservoirs destined to the most diverse uses. Ceara is the State with the highest number of regulation reservoirs, standing out the Jaguaribe River basin, with a high number of impoundments with a capacity of accumulation of more than $10 \mathrm{hm}^{3}$, especially the Orós, Banabuiú and Castanhão dams. In this basin, demands often exceed the drought flow, and, with the regulation of flows promoted by the dams, water availability is capable of increasing the water supply (ANA, 2015).

These reservoirs, as stated by Datsenko et al. (1999), are limnologically vulnerable to eutrophication because they are relatively shallow environments and with extensive areas and a long hydraulic retention time, which together with the climatic factors of high temperature and intense solar radiation for long hours daily, stimulate photosynthesis and biodegradation with consequences on water quality and biota in general.

In addition to natural events from the characteristics of the semiarid region, actions of anthropogenic origin, such as discharge of raw sewage, either directly or from the collecting networks, carry large amounts of pollutants to the springs. This process along with the deficiency of the systems for collection and final disposal of solid urban waste has resulted in the increasing degradation of the quality of public supply sources (Pegorini et al., 2005). One of the impacts of these loads is the eutrophication of the water sources, with consequent reduction of the quality of the water and elevation of the costs of implantation, operation and maintenance of the Water Treatment Stations (Carneiro et al., 2005).

The difficulties to be solved in relation to the eutrophication of both artificial and natural water bodies have become a problem, especially in tropical countries. In this sense, studies on the typology of lakes can contribute to effective solutions, however, the use of techniques of temperate regions applied to tropical regions has generated results that are often inadequate and even unfeasible to be used (Thornton \& Rast, 1993).

It is important to consider that the frequently used Trophic State Indices - TSI - have not been specifically developed for tropical regions and deserve attention in the interpretation of the data obtained for lentic systems located in the semiarid region of Northeast Brazil, since these ecosystems have completely different characteristics from the ecosystems from which the classical concepts of eutrophication originated. The main objective of 
this study was to propose a Trophic State Index for the Semiarid - TSI $_{S A}$, based on data from the Banabuiú basin, as a way to contribute to the evaluation of the trophic degree of reservoirs in this region of the State of Ceará.

\section{Material and Methods}

Data used in this work were made available by the Water Resources Management Company of the State of Ceará - COGERH. The years between 2010 and 2013 were considered for 18 artificial reservoirs in the Banabuiú basin (Figure 1).

The climate of the Banabuiú basin is tropical hot semiarid, predominant in the Brazilian Northeast, marked by the existence of two defined periods: one dry and long and one humid, short and irregular, with fall precipitations and average annual temperatures around $26^{\circ} \mathrm{C}$ at $28^{\circ} \mathrm{C}$. The municipalities that are part of the Banabuiú Hydrographic Basin present annual average precipitation around $725.4 \mathrm{~mm}$ (IPECE, 2010, 2011).

The Banabuiú basin has a considerable water deficit for all the municipalities included in it, due to the high temperatures and high evaporation rates, together with the low rainfall. In this way, the drainage in the natural drainage network is practically restricted to rainy periods. According to Fuck Júnior (2008), the pluviometric shortage is accentuated to the west, decreasing to the east of the basin (of the same latitude, but closer to the sea).

For the present study, monthly precipitation data of six pluviometric stations inserted in the Banabuiú basin, from 2010 to 2013, were considered. In 2010, the precipitation regime presented an annual rainfall of $483.1 \mathrm{~mm}$, the highest precipitation concentrated in April (185.4 mm), and in August and September no precipitation was registered in the basin $(0.0 \mathrm{~mm})$. In 2011, the annual rainfall of the basin was $861.2 \mathrm{~mm}$, surpassing the annual average of the basin $(725.4 \mathrm{~mm})$, presenting the highest rainfall from January to May.

In 2012, the precipitation regime observed in the river basin was well below the historical average monthly of the last 30 years, being considered the worst dry year since the last decades. With an annual rainfall of $237.3 \mathrm{~mm}$, the highest rainfall was in February $(82.3 \mathrm{~mm})$, while the other months had monthly rainfall below $50.0 \mathrm{~mm}$. In the year of 2013 the months of greatest precipitation were April and May, 109.5 and $95.8 \mathrm{~mm}$, respectively, with annual rainfall of $498.1 \mathrm{~mm}$ (Figure 2).

The water from the reservoirs of the Banabuiú basin is used for multiple purposes such as public supply, irrigation, recreation, aquaculture, among others, and this information is important for understanding the integration processes that occur between uses of the river basin and conservation or deterioration of the water quality of the reservoirs.

The main environmental aspects to the monitored dams in the Banabuiú basin are related to the contribution of sewage from the surrounding communities to the reservoirs, rearing of animals at the banks of the dams, where the accumulation of feces in the corrals is carried to the reservoir in

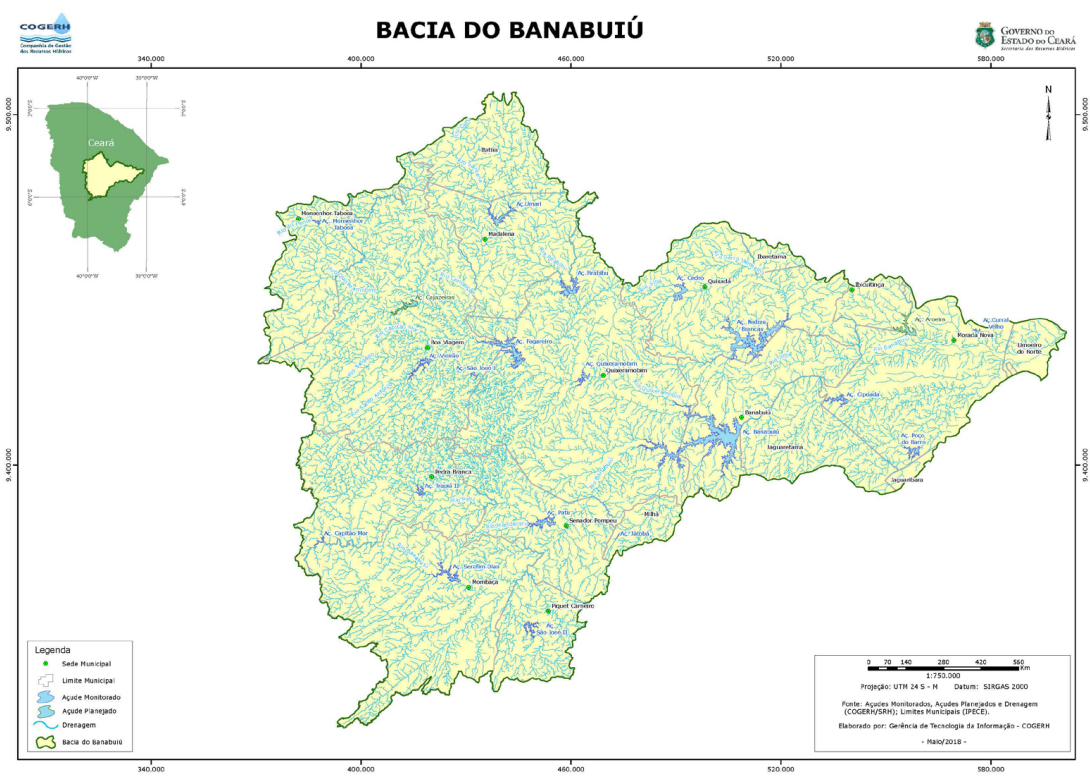

Figure 1. Location Map of the Banabuiú Basin. Source: Adapted Cogerh, 2009. 


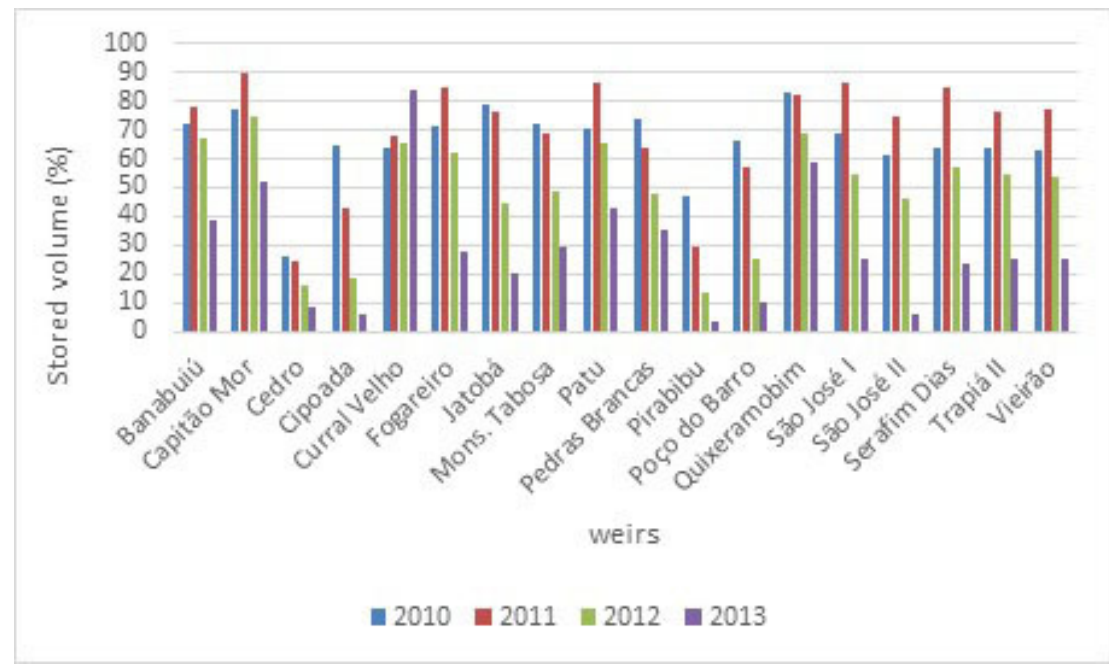

Figure 2. Average annual volume of the weirs of the Banabuiú Basin (2010 to 2013). Source: Cogerh, 2016.

the rainy season (agrochemicals and fertilizers) in agriculture, disposal of garbage around the reservoirs and later being transported to them during periods of rainfall, installation of tilapia nets (Tilapia) without an efficient management, causing degradation of the quality of waters, deforestation, burning and removal of riparian forests (COGERH, 2015).

For the purpose of evaluating the trophic status of the analyzed dams, COGERH provided the sampling data collected at $0.3 \mathrm{~m}$ depth. The collections on the surface of the reservoirs were useful to determine the availability of nutrients in the region of greater probability of phytoplankton distribution, to determine the interference of physical factors on this distribution, as well as the relative abundance of biomass in terms of chlorophyll a. Samplings were made with van Dorn bottle, a horizontal descent sampler with a capacity of 5.0L. Each reservoir was monitored always in the lacustrine zone, near the dam, in order to standardize the analysis of these parameters because they are, therefore, subjected to the same environmental constraints.

The software used to perform all the statistical analyses was SPSS v. 20.0. The results were examined and validated by evaluating their coherence and visual inspection. When detecting discrepant data, negative values and values below the detectable limit, these were excluded. These values are called outliers or atypical values, and may lead to errors in interpretation of the statistical test result applied to the samples. For the analysis of comparisons, we used the average data available for each variable in the month of collection.
The similarity in the trophic state of waters between the studied reservoirs of the Banabuiú basin was estimated using a multivariate analysis technique, Hierarchical Cluster Analysis (HCA), in SPSS 20.0 software. The water samples were grouped based on their similarity defined by the variation between the clustering coefficients of two consecutive groups, as described by Hair et al. (2005) and Palácio et al. (2011).

As the classifying variables adopted in this study are real variables and, therefore, measured on an interval scale, we adopted a combination of the squared Euclidean distance to compose the similarity matrix and the Ward linkage method algorithm (minimum variance method), in which the distance between two clusters is the sum of the squares between the two clusters made on all variables. At each stage of the clustering procedure, the internal sum of squares is minimized over all partitions (the complete set of disjoint or separated clusters) that can be obtained by combining two previous-stage aggregates (Hair et al., 2005; Palácio et al., 2009).

In the development of the Trophic State Index for the SemiArid $\left(\right.$ TSI $\left._{S A}\right)$, the same methodology was used to calculate a Water Quality Index (WQI), and from the water quality data of the reservoirs of the Banabuiú basin, an adaptation was developed for trophic classification based on local water reality. Aiming to describe the sequence of the process for obtaining the index, specifying the resources used as sources for the data and information, the flowchart below shows the process from the stage of data entry to the calculation of the proposed index (Figure 3). 


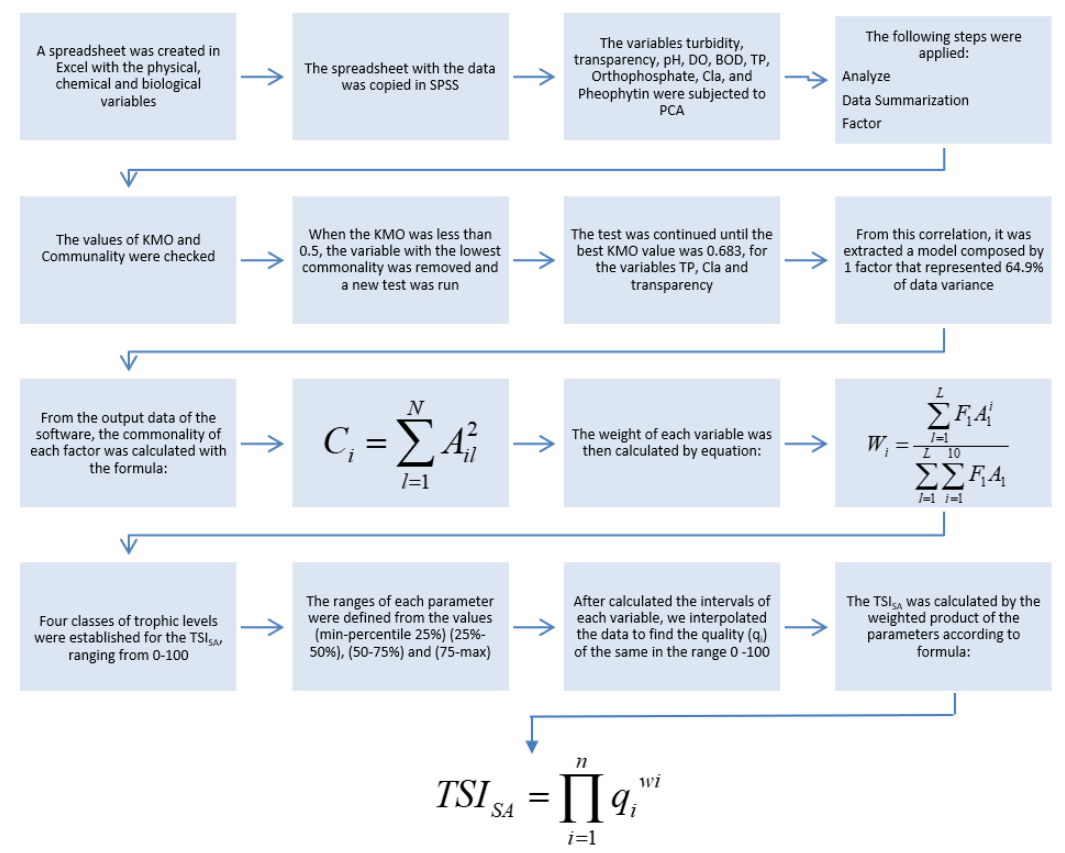

Figure 3. Process flowchart for obtaining the TSI $\mathrm{SA}_{\mathrm{A}}$

\section{Results}

\subsection{Hierarchical cluster analysis}

The similarity of the Banabuiú basin reservoirs, in relation to water eutrophication, was determined using the Multivariate Analysis/Hierarchical Cluster Analysis. In the dendrogram (Figure 4), which corresponds to the figure with rescaled clustering coefficients in which the lowest coefficient corresponds to 1 and the highest to 25 , after the interpolation of data, it was decided to make the optimal cutoff point at the rescaled distance 6, originating three distinct groups. Group I was the most representative, with nine reservoirs; Group II consisted of four reservoirs, and group III consisted of five reservoirs.

\subsection{Correlation between the variables for developing a $T_{S A}$ of the waters of the Banabuiu basin reservoirs}

The Principal Component Analysis (PCA) was applied to determine the TSI $\mathrm{SA}_{\text {of }}$ of the waters of the Banabuiú Basin reservoirs. The following variables were selected through multivariate analysis: total phosphorus, chlorophyll-a and transparency. The parameters cited were used to construct the correlation matrix. To evaluate the selected model, we analyzed the KMO value (Kaiser, 1974), which measures the adequacy of the sample. The KMO for the reservoir water model was 0.683 . The axes were rotated using the VARIMAX method, in order to facilitate the interpretation of the factors. A model

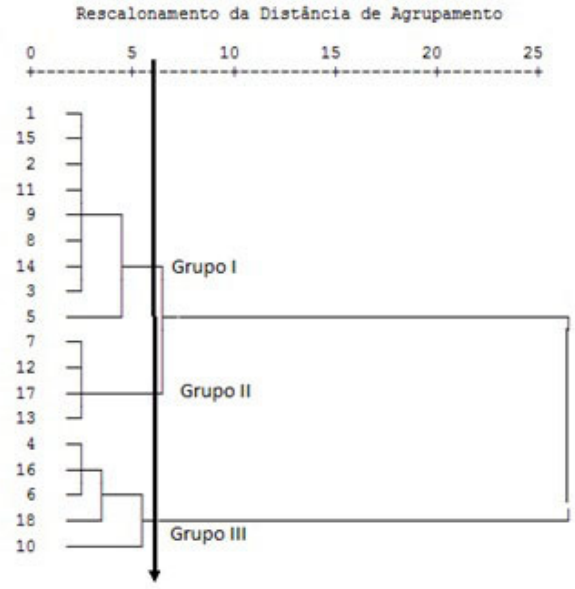

Figure 4. Dendrogram of the Banabuiú basin reservoirs, grouped according to water eutrophication. BAN: Banabuiú, COM: Capitão Mor, CED: Cedro, CIP: Cipoada, CRV: Curral Velho, FOG: Fogareiro, JAT: Jatobá, MNT: Mons. Tabosa, PTU: Patu, PEB: Pedras Brancas, PRB: Parabibu, PÇB: Poço do Barro, QXM: Quixeramobim, SJ I: São José I, SJ II: São José II, SRD: Serafim Dias, TRP II: Trapiá II, VIE: Vieirão.

composed of 1 factor representing $64.9 \%$ of the data variance was extracted (Table 1).

The Table below shows that the total phosphorus was the variable that had the lowest commonality, $63.6 \%$ of its variance was explained by the factor. The transparency had the highest commonality, with $66.6 \%$ explained by the factor. This component was more significant for the chlorophyll-a and 
transparency, presenting factor weights of 0.803 and 0.816 , respectively. The selected variables were given weights that are also identified in Table 1.

The Trophic State Index for the Semiarid $\left(\mathrm{TSI}_{\mathrm{SA}}\right.$ ) obeyed the equation 1 below, following the weighted product of the variables selected:

$$
\operatorname{TSI}_{S A}=q_{P t}^{0.330} \cdot q_{\text {Cla }}^{0.332} \cdot q_{\text {Transp }}^{0.338}
$$

\section{Where:}

$\mathrm{q}=$ water quality class in relation to the variable,

q ranges from 0 to 100

$\mathrm{Pt}=$ total phosphorus (mg. $\left.\mathrm{L}^{-1}\right)$

$\mathrm{Cla}=$ chlorophyll $-a\left(\mu \mathrm{g} \cdot \mathrm{L}^{-1}\right)$

Transp $=$ water transparency $(\mathrm{m})$

We considered 18 reservoirs with different aspects, trophic, morphological and hydrodynamic characteristics. Table 2 lists the descriptive statistics and the percentages of 25, 50, 75 of each set of the selected variable.

From the calculation of the minimum and maximum values and percentiles of the correlated parameters, four classes of trophic levels were established, organized in ascending order and divided into four subsets of data, corresponding to the categories oligotrophic (min-percentile $25 \%$ ), mesotrophic (25-50\%), eutrophic (50-75\%) and hypereutrophic (75-max). Thus, it was possible to set limits for each class of trophic state and determine the $\mathrm{q}_{\mathrm{i}}$ (quality of variables) for each site and sampling (Table 3).

The quality of the variables was represented by a dimensionless number ranging from 0 to 100 , such as the $T S I_{S A}$ scale. Following the reasoning that, the better the quality of the variable, the lower the value and the closer to 0 . The worse quality of the variable was in the range 80-100 (Table 3). Thus, the limit of the consumption pattern of the variable, according to CONAMA Resolution (357/05) (Brasil, 2005), was represented by $q_{i}=60$. Above this value, $q_{i}$ was considered poor and indicated that the variable was out of standards.

\section{Discussion}

From the formation of the groups, we sought to investigate, which of the water quality attributes of the Cluster Analysis was more significant to the point of influencing the separation, by the value of their concentrations. The mean, standard deviation and maximum and minimum values of the eutrophication attributes of the waters of each group of reservoirs in the Banabuiú basin can be seen in Table 4.

The reservoirs of group 1 presented the lowest mean concentrations of Total phosphorus and chlorophyll-a, $0.03 \mathrm{mg} . \mathrm{L}^{-1}$ and $9.41 \mu \mathrm{g} . \mathrm{L}^{-1}$,

Table 1. Correlation data between the parameters selected through the SPSS software.

\begin{tabular}{lccccc}
\hline \multicolumn{1}{c}{ Parameters } & KMO & Commonality & Variance & Factor 1 & Weight (Wi) \\
\hline Total phosphorus $\left(\mathbf{m g}^{-\mathrm{L}^{-1}}\right)$ & 0.683 & 0.636 & $64.9 \%$ & 0.797 & 0.330 \\
Clorofila $\mathbf{a}\left(\boldsymbol{\mu g} \cdot \mathrm{L}^{-1}\right)$ & - & 0.646 & - & 0.803 & 0.332 \\
Transparency $(\mathbf{m})$ & - & 0.666 & - & 0.816 & 0.338 \\
\hline
\end{tabular}

Table 2. Descriptive statistics of correlated parameters.

\begin{tabular}{lrrrrrrrr}
\hline \multicolumn{1}{c}{ Parameters } & \multirow{2}{*}{ Mean } & \multirow{2}{*}{ Min } & \multirow{2}{*}{ Max } & \multirow{2}{*}{ SD } & \multicolumn{3}{c}{ Percentiles } \\
\cline { 6 - 9 } & & & & & $\mathbf{2 5}$ & $\mathbf{5 0}$ & $\mathbf{7 5}$ \\
\hline Total phosphorus $(\mathrm{mg} / \mathrm{L})$ & 0.052 & 0.01 & 0.29 & 0.05867 & 0.013 & 0.036 & 0.064 \\
Chlorophyll-a $(\boldsymbol{\mu g} / \mathrm{L})$ & 20.699 & 0.02 & 98.79 & 22.928 & 3.36 & 11.01 & 31.315 \\
Transparency $(\mathrm{m})$ & 0.890 & 0.30 & 2.80 & 0.58890 & 0.5 & 0.7 & 1.2 & \\
\hline
\end{tabular}

Table 3. TSI $_{S A}$ matrix and equivalence with phosphorus, chlorophyll-a and transparency in reservoirs.

\begin{tabular}{|c|c|c|c|c|}
\hline $\begin{array}{c}\text { Trophic } \\
\text { categories }\end{array}$ & $\begin{array}{c}\text { Total phosphorus } \\
\left(\mathrm{mg}^{\left.-\mathrm{L}^{-1}\right)}\right.\end{array}$ & $\begin{array}{c}\text { Chlorophyll } \\
\left(\mu g \cdot \mathrm{L}^{-1}\right)\end{array}$ & $\begin{array}{c}\text { Transparency* } \\
(\mathrm{m})\end{array}$ & $\mathrm{TSI}_{\mathrm{SA}}$ \\
\hline \# Oligotrophic & $0.01-0.013$ & $0.02-3.36$ & $2.80-1.2$ & $0-40$ \\
\hline$\xi$ Mesotrophic & $0.013-0.036$ & $3.36-11.01$ & $1.2-0.7$ & $40-60$ \\
\hline * Eutrophic & $0.036-0.064$ & $11.01-31.31$ & $0.7-0.5$ & $60-80$ \\
\hline${ }^{E}$ Hypereutrophic & $0.064-0.29$ & $31.31-98.79$ & $0.5-0.3$ & $80-100$ \\
\hline
\end{tabular}

*For transparency, since the relation is inversely proportional, it is calculated the distribution with the value of $(-1)$. transparency.

Legend: \# - Oligotrophic; $\xi$ - Mesotrophic; * Eutrophic; $£$ - Hypereutrophic. 
Table 4. Mean values of the variables studied for the water eutrophication groups of the reservoirs in the Banabuiú basin.

\begin{tabular}{|c|c|c|c|c|}
\hline & STATISTICS & GROUP I & GROUP & GROUP III \\
\hline \multirow[t]{4}{*}{ TOTAL PHOSPHORUS (mg.L-1) } & Mean & 0.03 & 0.06 & 0.07 \\
\hline & SD & 0.03 & 0.06 & 0.03 \\
\hline & Minimum & 0.01 & 0.01 & 0.01 \\
\hline & Maximum & 0.27 & 0.29 & 0.27 \\
\hline \multirow[t]{4}{*}{ CHLOROPHYLL A $\left(\mu \mathrm{g} \cdot \mathrm{L}^{-1}\right)$} & Mean & 9.41 & 24.69 & 48.60 \\
\hline & SD & 10.55 & 25.75 & 31.35 \\
\hline & Minimum & 0.20 & 0.20 & 4.30 \\
\hline & Maximum & 74.76 & 79.30 & 98.79 \\
\hline \multirow[t]{4}{*}{ TRANSPARENCY $(\mathrm{m})$} & Mean & 1.06 & 0.62 & 0.3 \\
\hline & SD & 0.24 & 0.23 & 0.07 \\
\hline & Minimum & 0.30 & 0.30 & 0.10 \\
\hline & Maximum & 2.70 & 1.20 & 0.70 \\
\hline
\end{tabular}

respectively, and a higher mean transparency $(1.06 \mathrm{~m})$, indicating waters of better trophic quality, with concentrations within the limits established by CONAMA (357/05), for class 2 . They present moderate concentration of nutrients, limited water transparency, considering the regional characteristics and probably low phytoplankton biomass. Group 2 presented intermediate values for these attributes, being higher than the limits established by CONAMA (357/05), for class 2, indicating a grouping of waters with inferior quality. The reservoirs present characteristics that indicate the eutrophication process, due to chlorophyll-a and total phosphorus, probably due to land use and occupation surrounding the reservoirs. Group three showed the highest mean concentrations of phosphorus and chlorophyll-a and the lowest mean transparency.

Table 5 lists the results of the TSI $\mathrm{SA}_{\text {applied to }}$ the data of the reservoirs of the Banabuiú basin, from 2010 to 2013, from the groups formed in the Multivariate Analysis/Hierarchical Cluster Analysis. In total, 100 pairs of phosphorus, chlorophyll-a and transparency data were used for 18 sampling sites in the reservoirs of the Banabuiú basin.

Table 6 presents the confirmation of the cluster analysis that defined the formation of the groups, and from the selected trophic quality attributes subjected to the $\mathrm{TSI}_{\mathrm{SA}}$ calculation, it was observed that the reservoirs in group I presented trophic classification predominantly between oligotrophic (54.7\%) and mesotrophic (30.2\%), those of group II, eutrophic (44.4\%) and hypereutrophic (33.3\%) and reservoirs composing group III, were eutrophic $(39.1 \%)$ and hypereutrophic $(60.9 \%)$ in the study period.

The reservoirs that compose group I are more concentrated in the eastern and southern parts of the Banabuiú basin. The reservoirs that comprise this group presented trophic classification predominantly between oligotrophic, mesotrophic and eutrophic, and the Cipoada (CIP), Poço do Barro (PÇB) and Curral Velho (CRV) reservoirs presented the best trophic quality of their waters, with a medium TSI in the period studied, classifying them as predominantly oligotrophic. The three reservoirs are located in the municipality of Morada Nova and according to the data published in FUNCEME (2015), they presented a low number of cyanobacteria. These results can be related to the low rainfall index in the area, which consequently decreases the input of sediments and nutrients coming mainly from agricultural areas and the presence of corrals in the surroundings of the reservoirs.

The Curral Velho Reservoir, whose main purpose was the regulation of the affluent waters from the Castanhão Reservoir, thus composing the water transfer system (Castanhão - Curral Velho) to meet the demand for the Irrigation Perimeter Tabuleiros de Russas, as well as the Project Eixão of the waters that meet part of the capital's demand. Currently, this structure no longer serves this purpose, and only works during periods of floods, with the objective of preventing the flooding of the riverine communities, downstream of this reservoir. According to data from COGERH (2015), it can be inferred that due to the low rainfall, there were no contributions from the bleeding of the effluent lagoon of the Bethânia Dairy Industry (distant $1.18 \mathrm{Km}$ ), which later entered the reservoir and no pumping from the Banabuiú River (presence of effluents) to the reservoir.

The reservoirs that make up group II presented trophic classification predominantly between eutrophic and hypereutrophic. The two reservoirs with the greatest accumulation capacity are Quixeramobim (QXM) and Vieirão (VIE). 
Table 5. Matrix of Water Trophic Quality of the groups formed from the Multivariate Analysis/Hierarchical Cluster Analysis of the Banabuiú basin reservoirs.

\begin{tabular}{|c|c|c|c|c|c|c|c|c|}
\hline \multicolumn{3}{|c|}{ Group I } & \multicolumn{3}{|c|}{ Group II } & \multicolumn{3}{|c|}{ Group III } \\
\hline \multirow[t]{7}{*}{ BAN } & Feb/10 & $\xi 53$ & JAT & Mar/11 & $\xi 54$ & $\mathrm{CMO}$ & $\mathrm{Feb} / 11$ & $£ 83$ \\
\hline & Jan/11 & ${ }^{*} 64$ & & $\mathrm{Mar} / 12$ & $\xi 41$ & & $\mathrm{Dec} / 11$ & *77 \\
\hline & Aug/12 & $\# 13$ & & May/13 & $£ 80$ & & Jan/13 & *61 \\
\hline & Oct/12 & \#12 & QXM & Mar/10 & $\xi 46$ & & Apr/13 & *71 \\
\hline & Jan/13 & $\xi 58$ & & May/12 & $£ 84$ & TRII & Feb/11 & *74 \\
\hline & Apr/13 & \#5 & & Oct/12 & *76 & & Apr/12 & *69 \\
\hline & Jul/13 & $\# 13$ & & Apr/13 & *68 & & Jan/13 & *66 \\
\hline \multirow[t]{4}{*}{ SRD } & $\mathrm{Dec} / 11$ & *73 & & Jul/13 & $£ 81$ & & Apr/13 & *71 \\
\hline & May/12 & ${ }^{*} 68$ & VIE & Mar/12 & *66 & FOG & Mar/10 & $£ 84$ \\
\hline & Nov/12 & $\# 17$ & & May/12 & $£ 82$ & & Feb/11 & $£ 83$ \\
\hline & Mar/13 & \#23 & & Sep/12 & *66 & & Aug/11 & *67 \\
\hline \multirow[t]{7}{*}{ CED } & Feb/10 & ${ }^{*} 64$ & & Jan/13 & *69 & & May/12 & $£ 84$ \\
\hline & Feb/11 & $\xi 47$ & & $\mathrm{Jul} / 13$ & *76 & & Feb/13 & $£ 87$ \\
\hline & Aug/11 & $\xi 55$ & SJI & Dec/11 & $\xi 58$ & & May/13 & $£ 81$ \\
\hline & May/12 & *68 & & $\mathrm{Mar} / 12$ & ${ }^{*} 67$ & MNT & Feb/10 & $£ 85$ \\
\hline & Sep/12 & \#14 & & May/12 & ${ }^{*} 62$ & & Feb/11 & $£ 89$ \\
\hline & Oct/12 & \#5 & & Nov/12 & $£ 87$ & & Nov/12 & *70 \\
\hline & Jul/13 & *73 & & Jan/13 & $£ 88$ & & May/13 & $£ 92$ \\
\hline \multirow[t]{6}{*}{ PTU } & May/12 & $\# 11$ & & & & & Nov/13 & $£ 97$ \\
\hline & May/13 & $\xi 57$ & & & & PRB & Mar/10 & $£ 91$ \\
\hline & Mar/11 & $\xi 51$ & & & & & Aug/11 & $£ 88$ \\
\hline & Nov/12 & $\# 10$ & & & & & Feb/12 & $£ 95$ \\
\hline & Mar/13 & \#5 & & & & & May/12 & $£ 89$ \\
\hline & Jul/13 & ${ }^{*} 62$ & & & & & & \\
\hline \multirow[t]{8}{*}{ PEB } & Feb/10 & $\xi 45$ & & & & & & \\
\hline & Jan/11 & $\xi 43$ & & & & & & \\
\hline & Feb/12 & $\xi 55$ & & & & & & \\
\hline & Apr/12 & \#15 & & & & & & \\
\hline & Aug/12 & $\# 10$ & & & & & & \\
\hline & Jan/13 & * 61 & & & & & & \\
\hline & Jul/13 & \#15 & & & & & & \\
\hline & Oct/12 & \#5 & & & & & & \\
\hline \multirow[t]{7}{*}{ PÇB } & Mar/11 & \#32 & & & & & & \\
\hline & Aug/11 & $\xi 42$ & & & & & & \\
\hline & Mar/10 & $\xi 51$ & & & & & & \\
\hline & Mar/12 & $\# 16$ & & & & & & \\
\hline & May/12 & \#8 & & & & & & \\
\hline & Nov/12 & \#15 & & & & & & \\
\hline & Jun/13 & $\xi 54$ & & & & & & \\
\hline \multirow[t]{5}{*}{ SJII } & Mar/10 & $\xi 40$ & & & & & & \\
\hline & Feb/11 & $\xi 41$ & & & & & & \\
\hline & May/12 & $\xi 42$ & & & & & & \\
\hline & Mar/13 & \#4 & & & & & & \\
\hline & May/13 & $\xi 44$ & & & & & & \\
\hline \multirow[t]{6}{*}{ CIP } & Mar/10 & \#34 & & & & & & \\
\hline & Mar/11 & $\# 40$ & & & & & & \\
\hline & Feb/12 & \#29 & & & & & & \\
\hline & May/12 & \#4 & & & & & & \\
\hline & Mar/13 & \#5 & & & & & & \\
\hline & Jun/13 & \#16 & & & & & & \\
\hline \multirow[t]{3}{*}{ CRV } & Apr/12 & \#4 & & & & & & \\
\hline & Oct/12 & \#0 & & & & & & \\
\hline & Jan/13 & $\# 0$ & & & & & & \\
\hline
\end{tabular}

Legend: \# - Oligotrophic; $\xi$ - Mesotrophic; * - Eutrophic; $£$ - Hypereutrophic

Table 6. Trophic classification of the groups of reservoirs by applying the TSI $I_{S A}$.

\begin{tabular}{ccccc}
\hline \multirow{2}{*}{ Trophic Classification } & GROUP I & GROUP II & GROUP III \\
\cline { 2 - 3 } & Oligotrophic & 54.7 & 0.0 & $\%$ \\
Mesotrophic & 30.2 & 22.2 & 0.0 \\
Eutrophic & 15.1 & 44.4 & 0.0 \\
Hypereutrophic & 0.0 & 33.3 & 39.1 \\
\hline
\end{tabular}


According to the Funceme Water Quality System (FUNCEME, 2015), in the period from 2010 to 2012 , they presented very poor water quality and a high number of cyanobacteria.

The most relevant nutrient sources in these reservoirs are domestic sewage discharges, since the municipalities where the reservoirs of this group are located have practically no sewage treatment systems. When existing, the basic conditions of domestic effluent treatment consists only in the existence of individual solutions, cesspool/sink type, with precarious functionality from the sanitary point of view. Other sources are: affluence of soil particles, containing nutrients, due to water erosion and presence of livestock, mainly around the reservoir. In the semiarid conditions, eutrophication is also intensified by the low renewal rate of the mass of water stored in the reservoirs, which varies each year, depending on the intensity of the rainy season.

The reservoirs comprising group III are more concentrated in the western part of the Banabuiú basin, where the rainfall shortage is more pronounced and presented a trophic classification between hypereutrophic and eutrophic. The Fogareiro (FOG) and Pirabibu (PRB) reservoirs have the greatest accumulation capacity and are located in the municipality of Quixeramobim. The Pirabibú Reservoir had the TSI of all data analyzed classified as hypereutrophic. In 2009, the reservoir reached its greatest accumulation of water, about $70 \%$ of its capacity, in turn, in 2012, it was one of the twenty-three reservoirs of the State with a volume below 30\% (14.4\%). According to FUNCEME (2015), it has always presented a very high number of cyanobacteria, probably because since its construction, completed in 2000, the reservoir never overflowed and the numerous negative effects it causes in water bodies include the intense and uncontrolled development of aquatic macrophytes and phytoplankton; degradation of water quality with changes in composition, color, turbidity, transparency, increase of organic decay, causing, consequently, greater consumption of dissolved oxygen until anoxia; release of gases and production of bad odors; excessive growth of toxic algae, particularly cyanobacteria, which can lead to animal death, human contamination and gastrointestinal and skin problems (Environment Agency, 1998).

The construction of reservoirs constitutes a true tradition, simply "drowning" the existing forest, or resorting to the misleading solution of burning the forest, an initiative that, according to Branco
(1971), on the one hand, is beneficial for destroying most of the organic matter, but that would be slowly oxidized at the expense of the dissolved oxygen of the water itself and thereby enriching the medium with nutrients to the point of provoking undesired and rapid proliferation of aquatic vegetation with all the consequences that may result for the quality of water.

\section{Conclusion}

The HCA formed 3 distinct groups. The reservoirs of group I presented better trophic quality waters, with concentrations within the limits established by CONAMA (357/05), for class 2 waters. Group II presented a group of waters in process of eutrophication, probably due to land use and occupation surrounding the reservoirs. Group III was formed by reservoirs that presented very poor water quality and probably with a high number of cyanobacteria;

The $\mathrm{TSI}_{\mathrm{SA}}$ presented a simple methodology and easy interpretation of the data, based on the water quality of the artificial reservoirs located in the semiarid region of the State of Ceará. Therefore, its use may contribute to the reduction of errors in the inference of the trophic state of the reservoir of this region and should be considered as an indicator for further studies;

It is necessary to deepen the studies on the trophic state and the influence of climatic, hydrological and morphological factors of the reservoirs of the semiarid region of Ceará. Systematic monitoring in reservoirs complemented with nictemeral studies in rainy and dry seasons are needed to provide more accurate information and a more comprehensive view of the reservoirs and their basins. The generated database can be an important auxiliary to actions and policies for the management of these water resources.

Preventive measures should be taken to protect the quality of water, such as: treatment of wastewater before discharge to receiving bodies; maintenance of the minimum vegetation cover to mitigate the effects of erosion and transport of surface material into water bodies; restrictions on agricultural activities using chemical fertilizers and agrochemicals; restrictions on the implementation of certain types of industry. It should be noted that not only water monitoring can guarantee the protection of water quality, but also an adequate planning of land use and occupation in the river basin. 


\section{Acknowledgements}

We would like to thank the Water Resources Management Company of the State of Ceará (COGERH), for the data availability and the Environmental Sanitation Laboratory of the Federal Institute of Education, Campus Limoeiro do Norte, for support in the analysis throughout the research.

\section{References}

AGÊNCIA NACIONAL DE ÁGUAS - ANA. Conjuntura dos Recursos Hidricos: Informe 2014 [online]. Brasília: ANA, 2015 [viewed 29 Mar 2016]. Disponível em: http://conjuntura.ana.gov.br/docs/ conj2014_inf pdf.

ANDRADE, E.M., MEIRELES, A.C.M. and PALÁCIO, H.A.Q. O Semiárido cearense e suas águas. In: E.M. ANDRADE, O.J. PEREIRA and F.E.R. DANTAS, eds. Semiárido e o manejo dos recursos naturais: Uma proposta de uso adequado do capital natural. Fortaleza: Graphiti Gráfica/Editora Ltda., 2010, pp. 57-80.

BRANCO, S.M. Limpeza prévia de reservatórios de acumulação: estudo conceitual. Revista DAE, 1971, 82(31), 38-47.

BRASIL. Conselho Nacional do Meio Ambiente CONAMA. Resolução no 357, de 17 de março de 2005. Dispóe sobre a classificação dos corpos de água e diretrizes ambientais para o seu enquadramento, bem como estabelece as condiçôes e padrốes de lançamento de efluentes, e dá outras providências. Diário Oficial da Uniāo [da] República Federativa do Brasil, Poder Executivo, Brasília, DF, 18 mar. 2005, pp. 58-63.

CARNEIRO, C., PEGORINI, E.S. and ANDREOLI, C.V. Introdução. In: C.V. ANDREOLI and C. CARNEIRO. Gestão integrada de mananciais de abastecimento eutrofizados. Curitiba: Sanepar, 2005. pp. 27-44.

COMPANHIA DE GESTÁO DE RECURSOS HÍDRICOS - COGERH. Inventários Ambientais. Fortaleza: COGERH, 2015 [viewed 07 Oct. 2015]. Available from: http://www.hidro.ce.gov.br/mi/ midia/show/150.

DATSENKO, I.S., SANTAELLA, S.T.E. and ARAÚJO, J.C. Peculiaridades do processo de eutrofizaçáo dos açudes da região semi-árida. In: Anais do XX Congresso Brasileiro de Engenharia Sanitária e Ambiental. Rio de Janeiro: ABES, 1999, 1 CD-ROM.

ENVIRONMENT AGENCY. Aquatic eutrophication in England and Wales: A proposed management strategy. Bristol: Environment Agency, 1998, 36 p.

FUCK JÚNIOR, S.C.F. Subsídio à Gestáo Ambiental: descrição fisiográfica e análise funcional das bacias hidrográficas do Ceará. Revista Eletrônica do Curso de Geografia do Campus Jatai - UFG [online], 2008, (10), 41-71 [viewed 10 Nov. 2012]. Available from: http://www.jatai.ufg.br/geografia.

FUNDAÇÃO CEARENSE DE METEOROLOGIA E RECURSOS HÍDRICOS - FUNCEME. Calendário das chuvas no estado do Ceará. Fortaleza: conam, 2015 [viewed 16 Sept. 2015]. Available from: http://www. hidro.ce.gov.br/

HAIR, J.F.J., ANDERSON, R.E., TATHAM, R.L. and BLACK, W.C. Análise multivariada de dados. Tradução de Santanna, A. S.; Chaves Neto, A. Porto Alegre: Bookman, 2005. 593p.

KAISER, H.F. An index of factorial simplicity. Psychometrika, 1974, 39(1), 31-36. http://dx.doi. org/10.1007/BF02291575.

INSTITUTO DE PESQUISA E ESTRATÉGIA ECONÔMICA DO CEARÁ - IPECE. Anuário Estatístico, 2011. Fortaleza: IPECE, 2011.

INSTITUTO DE PESQUISA E ESTRATÉGIA ECONÔMICA DO CEARÁ - IPECE. Anuário Estatistico, 2010. Fortaleza: IPECE, 2010.

PALÁCIO, H.A.Q., ANDRADE, E.M., LOPES, F.B., ALEXANDRE, D.M.B. and ARRAES, F.D.D. Similaridade da qualidade das águas superficiais da bacia do Curu, Ceará, usando análise multivariada. Ciência Rural, 2009, 39(9), 2494-2500. http:// dx.doi.org/10.1590/S0103-84782009000900017.

PALÁCIO, H.A.Q., ARAÚJO, N.J.R., MEIRELES, A.C.M., ANDRADE, E.M., SANTOS, J.C.N. and CHAVES, L.C.G. Similaridade e fatores determinantes na salinidade das águas superficiais do Ceará, por técnicas multivariadas. Revista Brasileira de Engenharia Agricola e Ambiental, 2011, 15(4), 395-402. http://dx.doi.org/10.1590/S141543662011000400011.

PEGORINI, E.S., CARNEIRO, C. and ANDREOLI, C.V. Mananciais de abastecimento público. In: C.V. ANDREOLI and C. CARNEIRO. Gestão integrada de mananciais de abastecimento eutrofizados. Curitiba: Sanepar, 2005, pp. 47-82.

THORNTON, J.A. and RAST, W. A test of hypotheses relating to the comparative limnology and assessment of eutrophication in semi-arid man-made lakes. In: M. Straskabra, J.G. Tundisi, A. Duncan, eds. Comparative reservoir limnology on water quality management. London: Kluwer Academic Publishers, 1993, pp. 1-24. http://dx.doi.org/10.1007/978-94017-1096-1_1.

Received: 20 November 2017 Accepted: 11 September 2019 